\title{
Intestinal inflammation and tissue injury in response to heat stress and cooling treatment in mice
}

\author{
ZHIFENG LIU ${ }^{1 *}$, XUEGANG SUN ${ }^{2 *}$, JING TANG $^{3}$, YOUQING TANG $^{1}$, \\ HUASHENG TONG ${ }^{1}$, QIANG WEN ${ }^{1}$, YUNSONG LIU ${ }^{1}$ and LEI SU ${ }^{1}$ \\ ${ }^{1}$ Department of Intensive Care Unit, General Hospital of Guangzhou Military Command, Guangzhou 510010; \\ ${ }^{2}$ Key Laboratory of Molecular Biology, State Administration of Traditional Chinese Medicine, \\ School of Traditional Chinese Medicine, Southern Medical University, Guangzhou 510515; \\ ${ }^{3}$ Department of Anesthetize, Nanfang Hospital, Guangzhou 510515, P.R. China
}

Received November 22, 2010; Accepted March 2, 2011

DOI: $10.3892 / \mathrm{mmr} .2011 .461$

\begin{abstract}
Gut-derived endotoxin and pathogenic bacteria have been proposed to be important causative factors of morbidity and mortality due to heat stroke. However, the molecular mechanisms underlying the small intestinal lesions caused by heat stroke have yet to be well characterized. In order to verify the possible inflammatory pathogenesis of intestinal tissue injury, a mouse heat stroke model was established. Cooling treatment was applied, mimicking the clinical therapy. Morphologic changes in intestinal tissue and 10 cytokines and chemokines produced from ileum tissue were detected, and their correlation was analyzed. As a result, intestinal lesions in mice worsened with the increase in rectal core temperature (Tc) during heat stress. When heat stress was halted at a Tc of no more than $41^{\circ} \mathrm{C}$ followed by cooling treatment, pathological recovery from the injury of heat stress was observed. However, when cooling treatment was applied after the Tc reached $42^{\circ} \mathrm{C}$, the lesions continuously deteriorated until the animals succumbed. The levels of pro-inflammatory (IL-1 $\beta$, IL-2, IL-6 and TNF- $\alpha$ ) and anti-inflammatory (IL-10, IL-12p40) cytokines showed significant changes at different time points during the heat stress and cooling treatment, but no changes in GM-CSF, MCP-1, MIP- $1 \alpha$ and IL-4 were observed. Levels of IL-1 $\beta$, IL-10 and IL-12p40 were moreover significantly correlated with intestinal injury scores. A significant inverse linear correlation was observed between intestinal injury and IL-12p40 levels. In conclusion, this study provided insight into the inflammatory pathogenesis of intestinal tissue injury after heat stress and cooling treatment in a mouse model, and presented a potential biomarker for the evaluation of intestinal injury during heat stroke.
\end{abstract}

Correspondence to: Professor Lei Su, Department of Intensive Care Unit, General Hospital of Guangzhou Military Command, Guangzhou 510010, P.R. China

E-mail: serpentking@sina.com

${ }^{*}$ Contributed equally

Key words: heat stroke, intestinal injury, inflammatory response, cytokine, cooling treatment

\section{Introduction}

Heat stroke is a life-threatening illness that can be fatal if not appropriately managed. Although heat stroke has been recognized for centuries, a universally accepted definition of heat stroke is lacking, and its pathogenesis is not fully understood (1). Current knowledge suggests that the pathophysiologic responses to heat stroke are not due to the immediate effects of heat exposure, but are rather the result of a systemic inflammatory response syndrome (SIRS) that ensues following thermal injury. Even when treatment such as the adequate lowering of body temperature and intensive care is administered, heat stroke can often lead to multiple organ dysfunction syndrome (MODS) and death (2). A better understanding of the molecular mechanisms mediating tissue injury caused by direct heat stress or the subsequent inflammatory reaction is required for the development of clinical strategies to decrease the high mortality rates of severe heat stroke.

The gut is a vast pool of bacteria and endotoxin (lipopolysaccharide) in the body. Gut-derived endotoxin and pathogenic bacteria have been proposed to be important causative factors of morbidity and mortality from heat stroke $(3,4)$. Many studies that have pathologically examined the small intestine have revealed that lesions in this organ are common, and intestinal-derived endotoxemia has been observed in heat stroke cases $(5,6)$. Lambert described the gastrointestinal symptoms produced by intestinal barrier dysfunction and endotoxemia as warning signs ('canary in the coal mine') for the onset of circulatory collapse and multiple organ failure during exertional heat stroke (7).

Increased intestinal and epithelial permeability in sepsis and endotoxemia has been noted to be induced by proinflammatory cytokines such as interferon- $\gamma$, tumor necrosis factor- $\alpha$ (TNF- $\alpha$ ) and interleukin- $1 \beta$ (IL-1 $\beta$ ) (8). High circulating levels of cytokines in plasma, such as IL-1 $\beta$, IL-6 or IL-10, have also been observed in heat stroke affected animals and humans $(6,9,10)$. In vitro, heat shock was shown to induce cultured intestinal epithelial cells to produce certain cytokines (e.g., IL-6 and IL-8) (11) that can directly result in increased epithelial permeability and a high rate of apoptosis $(12,13)$. Cytokines and chemokines produced from $\mathrm{T}$ and $\mathrm{B}$ 
lymphocytes of the gut-associated lymphoid tissue (GALT), monocytes and macrophages, as well as mast cells are capable of infiltrating the intestinal mucosa and submucosa, and play an injurious or protective role during the inflammatory reaction in intestinal epithelial cells (14).

In order to verify the possible inflammatory pathogenesis of intestinal tissue injury, a heat stroke model was established in mice following which cooling treatment was applied, mimicking the clinical therapy. Intestinal tissue injury as well as cytokines and chemokines produced from ileum tissue were detected, and their correlation was analyzed.

\section{Materials and methods}

Animals. Pathogen-free 6- to 8-week old male BALB/c mice were housed in barrier cages under controlled environmental conditions ( $12 \mathrm{~h} \mathrm{light/dark}$ cycle, $55 \pm 5 \%$ humidity, $\left.23^{\circ} \mathrm{C}\right)$ at the Experimental Animal Center of Southern Medical University (Guangzhou, China), and were given free access to standard laboratory chow and water. Animal procedures were approved by the Animal Care and Use Committee of Southern Medical University, and the experiment was conducted according to the Guidelines for Animal Care of Southern Medical University.

Heat stress protocol and cooling treatment. Mice were fasted for $12 \mathrm{~h}$ prior to the experiment, but were allowed water ad libitum. After being stabilized for $6 \mathrm{~h}$ at an ambient temperature $\left(25 \pm 0.5^{\circ} \mathrm{C}\right)$ with a humidity of $35 \pm 5 \%, 64$ mice were divided into two groups: the control group $(n=8)$ and the heat stress (HS) group $(n=56)$. Then, the animals in the HS group were placed in a pre-warmed incubator maintained at $35.5 \pm 0.5^{\circ} \mathrm{C}$ with a relative humidity of $60 \pm 5 \%$, in the absence of food and water. The animals in the control group were sham-heated at a temperature of $25 \pm 0.5^{\circ} \mathrm{C}$ and a humidity of $35 \pm 5 \%$ for a time comparable to that of the HS group. The rectal core temperature (Tc) was continuously monitored with a rectal thermometer.

Mice in the heat stress group were further equally divided into seven groups ( $\mathrm{n}=8$ per group). The mice from four groups were kept in the incubator until the Tc reached $39^{\circ} \mathrm{C}, 40^{\circ} \mathrm{C}$, $41^{\circ} \mathrm{C}$ or $42^{\circ} \mathrm{C}$, respectively. Mice from the other three groups were removed from the incubator and allowed to cool at an ambient temperature of $25 \pm 0.5^{\circ} \mathrm{C}$ for $6 \mathrm{~h}$ after the Tc reached $40^{\circ} \mathrm{C}\left(40^{\circ} \mathrm{C} / 6 \mathrm{~h}\right), 41^{\circ} \mathrm{C}\left(41^{\circ} \mathrm{C} / 6 \mathrm{~h}\right)$ and $42^{\circ} \mathrm{C}\left(42^{\circ} \mathrm{C} / 6 \mathrm{~h}\right)$, respectively. During the cooling treatment, the Tc was continuously monitored with a rectal thermometer.

Histopathological analysis. Mice were anesthetized by intraperitoneal injection of urethane and sacrificed. Samples of ileum were quickly excised, sliced into transverse or longitudinal sections and fixed in 10\% neutral-buffered formalin. The tissues were then embedded in paraffin blocks, and serial sections were stained with hematoxylin and eosin for microscopic evaluation at a magnification of x200. Morphological changes were assessed and graded in a blinded manner by two certified veterinary pathologists using the intestinal injury score developed by Chiu et al (15).

Cytokine and chemokine measurement. Total proteins were extracted from the homogenized ileum tissues in extraction

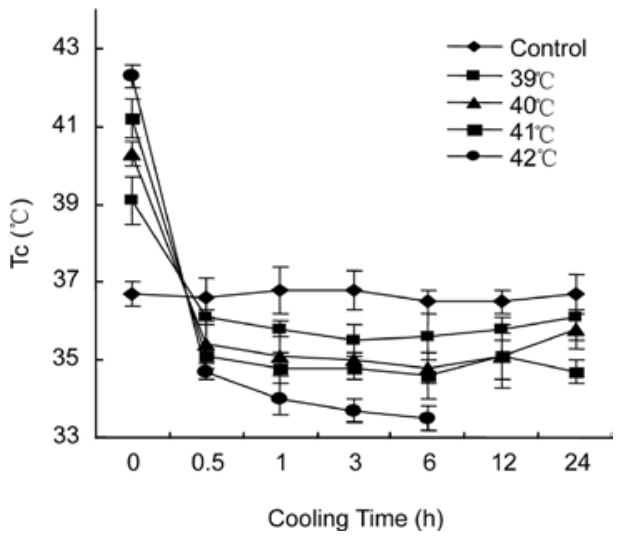

Figure 1. Effects of cooling treatment on the rectal core temperature $(\mathrm{Tc})$ of mice subjected to heat stress. Mice subjected to different degrees of heat stress were removed from the heat and placed into a $25^{\circ} \mathrm{C}$ environment. The Tc was monitored at 30-min intervals for $24 \mathrm{~h}$. Data are expressed as the means $\pm \mathrm{SD}$

buffer (20 mM Tris pH 0.5, $150 \mathrm{mM} \mathrm{NaCl}, 1.0 \mathrm{mM}$ EDTA, $1.0 \mathrm{mM}$ EGTA, $0.1 \%$ Triton X-100, $2.5 \mathrm{mM}$ sodium pyrophosphate, $1.0 \mathrm{mM} \beta$-pyrophosphate glycerol) supplemented with $1.0 \mathrm{mM} \mathrm{Na}_{3} \mathrm{VO}_{4}, 1.0 \mathrm{mM}$ PMSF and a protease inhibitor cocktail. After centrifugation at $10,000 \mathrm{x}$ g for $15 \mathrm{~min}$ at $4^{\circ} \mathrm{C}$, the supernatant was dialyzed against the PBS solution and protein concentrations were quantified using a micro BCA protein assay (Pierce, Rockford, IL).

Cytokines and chemokines in the intestinal extraction were analyzed simultaneously using a LiquiChip work station (Qiagen GMBH, Germany), which employs bead-based xMAP (flexible multi-analyte profiling) technology (16), according to the manufacturer's instructions. A commercial 10-plex kit specific for mouse cytokines and chemokines (Linco Co.) was used to analyze IL-1 1 , IL-2, IL-4, IL-6, IL-10, IL-12p40, TNF- $\alpha$, GM-CSF, MCP-1 and MIP-1 $\alpha$ expression. All samples were run in the same assay to avoid interassay expression.

Statistics. Data are presented as the means \pm standard deviation (SD) and were analyzed using the SPSS 15.0 statistical software package. One-way ANOVA was used for the comparison of qualitative variables. The correlation between intestinal injury scores and cytokine levels was calculated by Spearman's correlation or linear regression analysis. $p<0.05$ was considered significant for all statistical measures.

\section{Results}

Thermal response of mice to heat stress and cooling treatment. The thermal response of the mice to heat stress was described in detail in our previous study (17). Briefly, the Tc quickly rose above $39^{\circ} \mathrm{C}$ during the first $15 \mathrm{~min}$ of incubation, followed by a descent to $\sim 38^{\circ} \mathrm{C}$. After a slow increase over $\sim 3 \mathrm{~h}$, the Tc rose above $42^{\circ} \mathrm{C}$. The Tc of the sham-heated animals experienced no significant changes during the experiment.

All the animals with a $\mathrm{Tc}$ above $42^{\circ} \mathrm{C}$ succumbed to heat stroke, either with the Tc further increasing to $43^{\circ} \mathrm{C}$ in the incubator within $15 \mathrm{~min}$ or within $385 \pm 47 \mathrm{~min}$ after the immediate application of cooling treatment. Mice in the other 

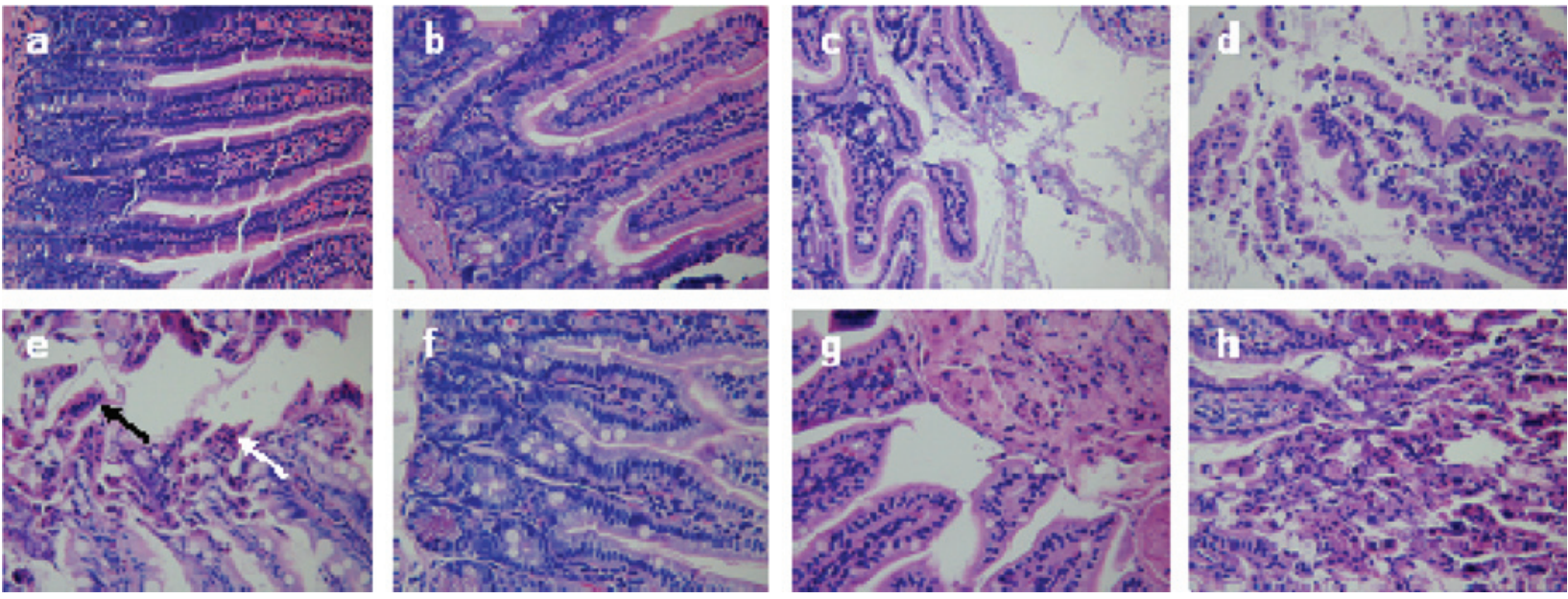

Figure 2. Pathological changes in the ileum of mice during heat stress and cooling treatment (magnification, $\mathrm{x} 200$ ). (a) Normal ileum and villi; ileum of mice whose Tc reached (b) $39^{\circ} \mathrm{C}$, (c) $40^{\circ} \mathrm{C}$, (d) $41^{\circ} \mathrm{C}$ and (e) $42^{\circ} \mathrm{C}$; and after cooling for $6 \mathrm{~h}$ following Tc, whose Tc reached (f) $40^{\circ} \mathrm{C}$, (g) $41^{\circ} \mathrm{C}$ and (h) $42^{\circ} \mathrm{C}$. No marked damage to the small intestinal mucosa was observed (a and b). When the Tc further increased (c-e), the injury to the ileum was mainly located in the villi, with progressive epithelial necrosis (white arrow, e) and loss and villi desquamation (black arrow, e). When cooling was applied after the Tc reached $42^{\circ} \mathrm{C}$, the lesions were further aggravated until the animals succumbed (h). However, if the Tc only reached 41 or $40^{\circ} \mathrm{C}$ during the heat stress procedure and was followed by cooling, the absorption of exfoliated enterocytes and the recovery of villi were detected ( $\mathrm{f}$ and $\mathrm{g}$ ).

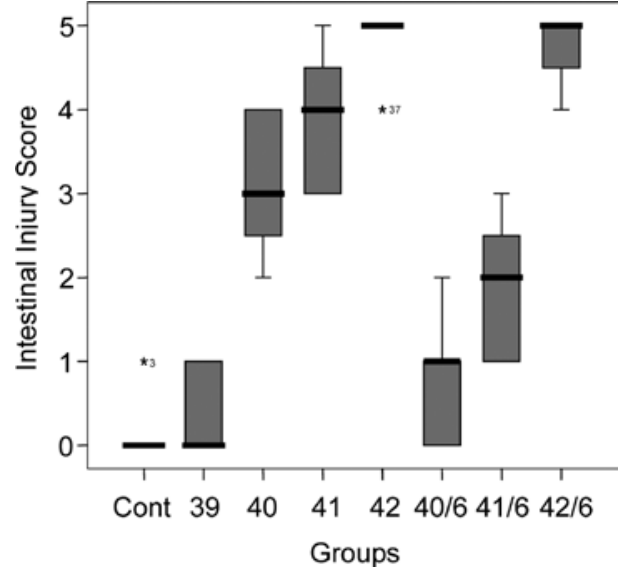

Figure 3. Chiu scores of intestinal injury in mice subjected to heat stress and cooling treatment. Morphological changes in the ileum of mice subjected to heat stress and cooling treatment were assessed and graded in a blindec manner by two certified veterinary pathologists using the Chiu intestinal injury score. There were 8 groups: the sham-heated group (Cont), groups whose $\mathrm{Tc}$ respectively reached $39,40,41$ and $42^{\circ} \mathrm{C}(39,40,41,42)$, and groups in which the animals were removed from the incubator and allowed to cool at an ambient temperature of $25 \pm 0.5^{\circ} \mathrm{C}$ for $6 \mathrm{~h}$ after the Tc reached $40^{\circ} \mathrm{C}(40 / 6), 41^{\circ} \mathrm{C}(41 / 6)$ and $42^{\circ} \mathrm{C}(42 / 6)$

groups survived for more than $24 \mathrm{~h}$. After removal from the heat conditions and placement in a $25^{\circ} \mathrm{C}$ environment, these mice had a quick decrease in $\mathrm{Tc}$ to around $35^{\circ} \mathrm{C}$ within $30 \mathrm{~min}$ (Fig. 1). The higher the Tc reached during the heat stress procedure, the less the Tc decreased with cooling treatment. Three hours after the cooling treatment, the Tc of the mice in the 39,40 , and $41^{\circ} \mathrm{C}$ HS groups reached nearly the lowest values. Then, the $\mathrm{Tc}$ of the mice in the $39^{\circ} \mathrm{C}$ group gradually increased, reaching that of the control mice, while the mice in the 40 and $41^{\circ} \mathrm{C}$ groups remained hypothermic for $24 \mathrm{~h}$, and the $\mathrm{Tc}$ of the mice in the $42^{\circ} \mathrm{C}$ group further decreased until the animals succumbed. The lowest value of Tc was $33.5 \pm 0.3^{\circ} \mathrm{C}$ at $6 \mathrm{~h}$ after the application of cooling treatment.
Tissue histopathology. Histopathologic examination was performed on the small intestine (ileum). Representative photomicrographs are shown in Fig. 2. In the sham-heat control group and the Tc $39^{\circ} \mathrm{C}$ group, no marked damage was observed in small intestinal mucosa (Fig. 2A and B). When the Tc was further increased, the injury to the ileum was mainly located in the villi with progressively epithelial necrosis, loss and villi desquamation (Fig. 5C-E). Even when cooling treatment was applied, if the Tc had reached $42^{\circ} \mathrm{C}$ during the heat stress procedure the lesions were further aggravated until the animals succumbed (Fig. 5H). However, if the Tc reached only 40 or $41^{\circ} \mathrm{C}$ and was followed by cooling treatment at an ambient temperature, the absorption of exfoliated enterocytes and the recovery of villi were detected (Fig. 5F and G).

Fig. 3 shows the mean scores of intestinal injury in the control and HS groups. Compared with those of the control group, the intestinal injury scores of the 40,41 , and $42^{\circ} \mathrm{C} \mathrm{HS}$ groups were significantly increased (all $\mathrm{p}<0.001$ ). The mean injury score in the $42^{\circ} \mathrm{C}$ group was significantly higher than that of the 40 and $41^{\circ} \mathrm{C}$ groups (both $\mathrm{p}<0.01$ ). After cooling treatment, the intestinal injury scores of the 40 and $41^{\circ} \mathrm{C}$ groups were significantly decreased (both $\mathrm{p}<0.01$ ). Consistent with the morphological changes, the mean injury score of the $42^{\circ} \mathrm{C} / 6 \mathrm{~h}$ group reached the highest values.

Intestinal cytokine and chemokine response. GM-CSF, IL-4, MCP-1 and MIP-1 $\alpha$ levels did not show any significant changes at any time point under heat stress conditions or during cooling treatment (data not shown). The other six cytokines, including IL-1 $\beta$, IL-2, IL-6, IL-10, IL-12p40 and TNF- $\alpha$, showed significant changes at different time points (Fig. 4).

$I L-1 \beta$. HS mice in the $39,40,41$ and $42^{\circ} \mathrm{C}$ groups showed significantly higher levels of IL-1 $\beta$ compared with the controls. After the cooling treatment, IL-1 $\beta$ levels underwent further significant increases in the $41^{\circ} \mathrm{C} / 6 \mathrm{~h}$ and $42^{\circ} \mathrm{C} / 6 \mathrm{~h}$ groups, but 

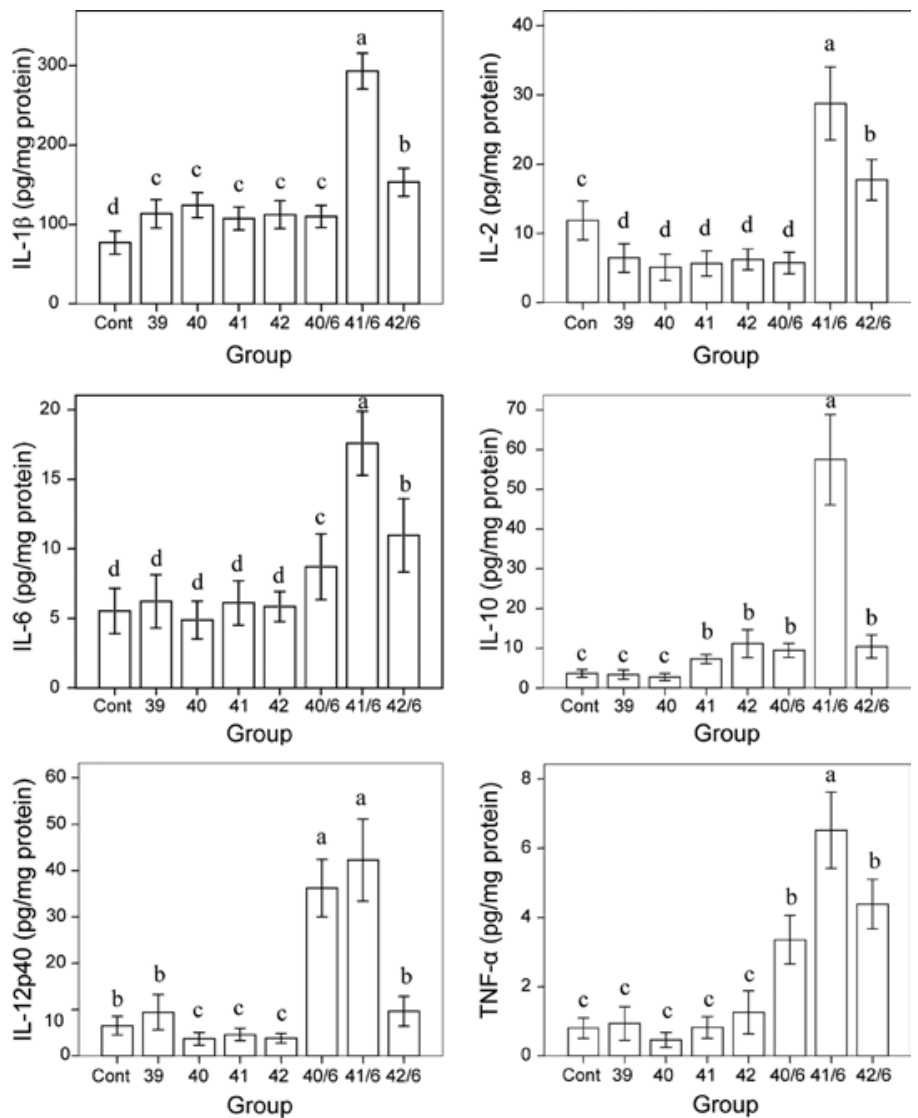

Figure 4. Changes in the intestinal cytokines of mice subjected to heat stress and cooling treatment. Ten cytokines and chemokines produced from ileum tissue were detected in mice subjected to heat stress and cooling treatment. No changes in GM-CSF, MCP-1, MIP-1 $\alpha$ and IL-4 were observed (data not shown). Eight groups are represented, as in Fig. 3. Multiple comparisons among the 8 groups were performed, and the same letter indicates that there was no significant difference; otherwise, $\mathrm{p}<0.05$.

Table I. Correlations analysis between intestinal injury scores and intestinal cytokines

\section{Scores}

IL-10

IL-1 $\beta$

IL-12p40

Spearman's Q scores

Correlation

1.000

$0.324^{\mathrm{a}}$

$0.338^{\mathrm{a}}$

$-0.421^{\mathrm{a}}$

Coefficient

Significance (two-tailed)

0.009

0.006

0.00

No.

IL-10

\section{Correlation}

$0.324^{\mathrm{a}}$

1.000

$0.506^{\mathrm{a}}$

$0.441^{\mathrm{a}}$

Coefficient

Significance (two-tailed)

0.009

64

64

0.000

0.000

No.

\section{Coefficient}

0.006

0.000

0.002

Significance (two-tailed)

IL-12p40

\section{Correlation}

$-0.421^{\mathrm{a}}$

$0.441^{\mathrm{a}}$

$0.373^{\mathrm{a}}$

Coefficient

Significance (two-tailed)

0.001

0.000

0.002

No.

${ }^{\mathrm{a}}$ Correlations were considered significant at $\mathrm{p}<0.01$ (two-tailed). 
not in the $40^{\circ} \mathrm{C} / 6 \mathrm{~h}$ group. A greater increase was observed in the $41^{\circ} \mathrm{C} / 6 \mathrm{~h}$ group than in the $42^{\circ} \mathrm{C} / 6 \mathrm{~h}$ group.

$I L-2$. IL-2 levels in the $39,40,41$ and $42^{\circ} \mathrm{C}$ groups were significantly reduced compared with the control mice. However, after the cooling treatment, IL-2 levels were significantly increased in the $41^{\circ} \mathrm{C} / 6 \mathrm{~h}$ and $42^{\circ} \mathrm{C} / 6 \mathrm{~h}$ groups, but not in the $40^{\circ} \mathrm{C} / 6 \mathrm{~h}$ group, and a greater increase was observed in the $41^{\circ} \mathrm{C} / 6 \mathrm{~h}$ group than in the $42^{\circ} \mathrm{C} / 6 \mathrm{~h}$ group.

IL-6. Compared with the control mice, intestinal IL-6 expression showed a tendency to increase in the 39, 40, 41 and $42^{\circ} \mathrm{C}$ groups, but did not achieve significance. After the cooling treatment, all mice showed a significant increase in IL- 6 production. The greatest increase in IL- 6 was observed in the $41^{\circ} \mathrm{C} / 6 \mathrm{~h}$ group, and a greater increase in IL- 6 was observed in the $42^{\circ} \mathrm{C} / 6 \mathrm{~h}$ group than in the $40^{\circ} \mathrm{C} / 6 \mathrm{~h}$ group.

IL-10. Intestinal IL-10 levels were comparable in the control mice and in mice with a low degree of heat stress (39 and $40^{\circ} \mathrm{C}$ groups). A higher degree of heat stress (41 and $42^{\circ} \mathrm{C}$ groups) induced a significant increase in IL-10 in the intestine. After the cooling treatment, the mice showed a further significant elevation in IL-10 levels in the $41^{\circ} \mathrm{C} / 6 \mathrm{~h}$ group, but not in the $40^{\circ} \mathrm{C} / 6 \mathrm{~h}$ or $42^{\circ} \mathrm{C} / 6 \mathrm{~h}$ groups.

$I L-12 p 40$. Intestinal IL-12p40 levels were increased in the control mice and the $39^{\circ} \mathrm{C}$ group compared with the other HS groups, including the 40,41 and $42^{\circ} \mathrm{C}$ groups. Cooling treatment induced a significant increase in IL-12p40 levels in the $40^{\circ} \mathrm{C} / 6 \mathrm{~h}$ and $41^{\circ} \mathrm{C} / 6 \mathrm{~h}$ groups, but not in the $42^{\circ} \mathrm{C} / 6 \mathrm{~h}$ group.

$T N F-\alpha$. Intestinal TNF- $\alpha$ levels in the control mice were comparable to those of all the HS groups, including the 39, 40, 41 and $42^{\circ} \mathrm{C}$ groups. Cooling treatment induced a significant increase in TNF- $\alpha$ production in all the HS groups compared with the control group, with the greatest increase occuring in the $41^{\circ} \mathrm{C} / 6 \mathrm{~h}$ group.

Correlation analysis. IL-1 $\beta$, IL-10 and IL-12p40 showed a significant (positive or inverse) correlation with intestinal injury scores $(r=0.338, p=0.006 ; r=0.324, p=0.009 ; r=-0.421$, $\mathrm{p}=0.01$, respectively) (Table I). No correlation was observed between intestinal injury scores and the other cytokines or chemokines (all $\mathrm{p}>0.05$, data not shown). Positive correlations were also detected among IL-1 $\beta$, IL-10 and IL-12p40 levels $(\mathrm{r}=0.506, \mathrm{p}=0.000 ; \mathrm{r}=0.373, \mathrm{p}=0.002 ; \mathrm{r}=0.441, \mathrm{p}=0.000$, respectively; Table I). In addition, a significant linear correlation was found between intestinal injury and IL-12p40 levels $(\mathrm{p}<0.001)$, with a coefficient for the linear regression correlation of $\mathrm{r}=-0.881$.

\section{Discussion}

Cooling treatment is an essential therapy for heat stroke patients. In the present study, cooling treatment was applied to mice subjected to heat stress in order to mimic clinical therapy, and its effects on changes in Tc were determined. Although hypothermia in heat recovery was investigated in other studies $(9,18-20)$, this is the first study to note detailed changes in Tc during cooling treatment. The results showed that the Tc of mice subjected to heat stress dropped below normal levels within $30 \mathrm{~min}$ of removal from heat and placement in a $25^{\circ} \mathrm{C}$ environment. Notably, the higher the Tc of the heat stressed animal reached, the lower the Tc decreased with the application of cooling treatment. When the cooling treatment was applied after the Tc had reached $42^{\circ} \mathrm{C}$, the Tc kept decreasing until the animals succumbed. Heat-induced hypothermia is thought to be crucial in the recovery and survival from life-threatening Tc increases, but our findings clearly indicate that a persistently low Tc is also very dangerous. Little is known about the mechanisms mediating this response. The elevation of certain cytokines as the endogenous pyrogen or thermal-regulator dysfunction from damage to the hypothalamus during heat stress and cooling treatment may contribute to the responses described above. Moreover, animals with a Tc that rose above $42^{\circ} \mathrm{C}$ succumbed immediately, despite cooling at an ambient temperature, while all the other HS group mice survived for more than $24 \mathrm{~h}$. This finding is consistent with other studies, and indicates that the core temperature and timing of cooling are key factors to reducing mortality due to heat stroke $(6,21)$.

Tissue damage is a common manifestation of heat stroke syndrome, and the high mortality rate observed in heat stroke has been considered secondary to multi-organ dysfunction $(22,23)$. Since 1986, the gastrointestinal tract had been called the 'motor' of multiple organ failure (24), and presently the key role of intestinal injury in critical illness, including heat stroke, is well accepted $(6,25,26)$. Our study is the first to describe the detailed pathological changes and injury scores of the small intestine in mice, not only during the application different degrees of heat stress, but also throughout the cooling treatment. The results show that the lesions in the small intestine were progressively aggravated with the increase in the Tc of the mice during heat stress. Of note, if the Tc only reached 40 or $41^{\circ} \mathrm{C}$ and was followed by cooling treatment, signs of pathological recovery were detected. However, the lesions were further aggravated until the animals succumbed when cooling treatment was applied after a Tc of $42^{\circ} \mathrm{C}$ was reached. Thus, there must be mechanisms at work that induce injury to the small intestine other than the direct thermal effect. The inflammatory pathogenesis of intestinal tissue injury may contribute to this phenomenon.

Inflammatory injury to tissues has been well described, and several pro- and anti-inflammatory cytokines have been observed to be elevated in the circulation of heat stroke patients $(3,5,27,28)$. Although circulating cytokines may also indirectly contribute to tissue damage, it should be noted that the concentrations of cytokines are different in the circulation and tissue, the latter of which are likely more important for the direct effects of these substances on tissue injury. Thus, we reported the changes of 10 cytokines and chemokines produced in the ileum tissue of mice subjected to heat stress and cooling treatment, and their correlation with intestinal injury was analyzed.

The levels of GM-CSF, MCP-1, MIP-1 $\alpha$, as the key chemokines, and of IL-4, as an important anti-inflammatory cytokine, did not show any significant changes at any time point during the application of heat stress or cooling treatment, but the other 6 cytokines, including IL-1 $\beta$, IL-2, IL-6, IL-10, IL-12p40 and TNF- $\alpha$, showed significant changes at different time points, in part consistent with previous studies on inflammatory medium in the plasma of heat stroke mice or baboons $(6,9)$, but also differing greatly in terms of cytokine categories and the time points of release from the mouse tissue during the heat stress and cooling treatment. 
The relatively high levels of IL-1 $\beta$ present in the normal intestine play an essential role in protecting the mucosa from bacteria colonizing the gut, but an overdose of IL-1 $\beta$ can injure the intestinal epithelium, resulting in dysfunction, apoptosis or even necrosis (12). In our study, heat stress induced a high level of IL-1 $\beta$ in the ileum, and after cooling treatment a further increase in IL-1 $\beta$ levels was observed. There was a significant positive correlation between IL-1 $\beta$ levels and intestinal injury scores, which indicated the contribution of IL-1 $\beta$ to the intestinal injury. The high IL- $\beta$ levels and low intestinal injury scores in the $41^{\circ} \mathrm{C} / 6 \mathrm{~h}$ group may be attributed to the protective role of high IL-1 $\beta$ expression in inducing the production of anti-inflammatory cytokines (IL-10 and IL-12p 40, r=0.506, $p=0.000 ; r=0.373, p=0.002$, respectively) and to its anti-bacterial activity.

IL-2, as an important pro-inflammatory cytokine, was inhibited in the ileum of mice during heat stress, but increased during the cooling treatment after a high Tc was reached, except in the $40^{\circ} \mathrm{C} / 6 \mathrm{~h}$ group. No correlation between intestinal IL-2 levels and the degree of tissue injury was found, thus further investigations must be performed to elucidate this response. The levels of IL- 6 and TNF- $\alpha$, as the key proinflammatory cytokines, changed in the ileum following the same pattern during the heat stress and cooling treatment. Increases in both cytokine levels were only observed in mice during the cooling treatment, and were not correlated with intestinal injury scores. It is difficult to explain this phenomenon. However, a study by Hershko provided evidence that IL-6 induces thermotolerance in a specific fashion in human intestinal epithelium (29). Moreover, IL-10 may activate the IL-6 gene in stimulated enterocytes by up-regulating the expression and activity of C/EBP, and IL-6 may be an antiinflammatory cytokine that exerts protective effects in the gut mucosa and enterocytes $(30,31)$. Thus, whether IL- 6 acts as an anti-inflammatory cytokine that inhibits the role of TNF- $\alpha$ in intestinal injury requires further study.

IL-10 is mainly produced by T cells and macrophages, and possesses both anti-inflammatory and immunosuppressive properties (32). In our study, only a high degree of heat stress induced a significant increase in IL-10 in mice, and only the mice in the $41^{\circ} \mathrm{C} / 6 \mathrm{~h}$ group showed a further significant elevation in IL-10 levels after the cooling treatment. Although there was also a positive correlation between intestinal IL-10 levels and tissue injury scores, it is unclear whether the changes in this cytokine were induced by the intestinal injury or vice versa.

IL-12p40 is known as an IL-12 receptor antagonist since it binds to the IL-12 receptor, but fails to induce a signal (33). Thus, it functions as a natural inhibitor to decrease the pro-inflammatory function of IL-12. Of note, we observed a significant linear correlation between intestinal injury and IL-12p40 levels, which indicates that IL-12p40 may function as a biomarker for evaluating the degree of the intestinal lesions.

Our statistical analysis also found a significant correlation between the Tc and intestinal injury scores in mice during the application of heat stress and cooling treatment. Moreover, a greater increase in all the cytokines was observed in the $41^{\circ} \mathrm{C} / 6 \mathrm{~h}$ group compared to the $42^{\circ} \mathrm{C} / 6 \mathrm{~h}$ group, but the latter had the most severe intestinal injury. In addition, the animals in the $42^{\circ} \mathrm{C} / 6 \mathrm{~h}$ group succumbed to the heat stress, while the animals in the $41^{\circ} \mathrm{C} / 6 \mathrm{~h}$ group survived for more than $24 \mathrm{~h}$, indicating that the $\mathrm{Tc}$ was the key factor not only for the outcome of heat stroke, but also for the intestinal inflammatory reaction. A Tc of $41^{\circ} \mathrm{C}$ may be the trigger of 'heat-induced SIRS', characterized by high levels of pro- and anti-inflammatory cytokines during cooling treatment.

Some limitations of this study were that our heat stroke model of mice did not fully represent the Tc changes and organ manifestation in heat stroke patients. Moreover, intestinal functional data, such as endotoxin concentrations in the systemic circulation, were not detected, and the relationship and eternal molecular mechanisms between the changes of certain cytokines and tissue damage was not well explained. Thus, further study is warranted.

In conclusion, our study provided the potential inflammatory pathogenesis of intestinal tissue injury in an animal model with heat stress and cooling treatment, suggested the probable presentation of heat-induced SIRS, and presented a potential biomarker for the evaluation of intestinal injury during heat stroke.

\section{Acknowledgements}

The authors thank Professors Bing-De Luo and Jin-Qiang Guo of the Department of Heat Environmental Medicine and Professors Lei Yang and Wei Wang of the Department of Pathology, Southern Medical University, for their invaluable technical assistance with heat stress experimentation and pathological examinations. This work was supported by a grant from the China Postdoctoral Science Foundation (no. 200902659), the National Natural Science Foundation of China (no. 81071529) and the Guangdong Natural Science Foundation (nos. 10151001002000001 and 9151001002000021).

\section{References}

1. Lim CL and Mackinnon LT: The roles of exercise-induced immune system disturbances in the pathology of heat stroke: the dual pathway model of heat stroke. Sports Med 36: 39-64, 2006.

2. Bouchama A and Knochel JP: Heat stroke. N Engl J Med 346: 1978-1988, 2002.

3. Bouchama A, Parhar RS, El-Yazigi A, Sheth K and Al-Sedairy S: Endotoxemia and release of tumor necrosis factor and interleukin 1 alpha in acute heat stroke. J Appl Physiol 70: 2640-2644, 1991.

4. Gathiram P, Gaffin SL, Brock-Utne JG and Wells MT: Time course of endotoxemia and cardiovascular changes in heatstressed primates. Aviat Space Environ Med 58: 1071-1074, 1987.

5. Bouchama A, Hammami MM, Al-Shail E and De Vol E: Differential effects of in vitro and in vivo hyperthermia on the production of interleukin-10. Intensive Care Med 26: 1646-1651, 2000.

6. Bouchama A, Roberts G, Al Mohanna F and et al: Inflammatory, hemostatic, and clinical changes in a baboon experimental model for heat stroke. J Appl Physiol 98: 697-705, 2005.

7. Lambert GP: Intestinal barrier dysfunction, endotoxemia, and gastrointestinal symptoms: the 'canary in the coal mine' during exercise-heat stress? Med Sport Sci 53: 61-73, 2008.

8. Wang Q, Guo XL, Wells-Byrum D, Noel G, Pritts TA and Ogle CK: Cytokine-induced epithelial permeability changes are regulated by the activation of the p38 mitogen-activated protein kinase pathway in cultured Caco-2 cells. Shock 29: 531-537, 2008.

9. Leon LR, Blaha MD and DuBose DA: Time course of cytokine corticosterone, and tissue injury responses in mice during heat strain recovery. J Appl Physiol 100: 1400-1409, 2006. 
10. Lu KC, Wang JY, Lin SH, Chu P, and Lin YF: Role of circulating cytokines and chemokines in exertional heat stroke. Crit Care Med 32: 399-403, 2004

11. Wang Q, Guo XL, Noel G and Ogle C: Heat shock stress ameliorates cytokine mixture-induced permeability by downregulating the nitric oxide and signal transducer and activator of transcription pathways in Caco-2 cells. Shock 27: 179-185, 2007.

12. Swank GM, Lu Q, Xu DZ, Michalsky M and Deitch EA: Effect of acute-phase and heat-shock stress on apoptosis in intestinal epithelial cells (Caco-2). Crit Care Med 26: 1213-1217, 1998.

13. Hu S, Claud EC, Musch MW and Chang EB: Stress granule formation mediates the inhibition of colonic Hsp70 translation by interferon-gamma and tumor necrosis factor-alpha. Am J Physiol Gastrointest Liver Physiol 298: G481-G492, 2010.

14. Aller MA, Vara E, Garcia C, Palma MD, Arias JL, Nava MP and Arias J: Proinflammatory liver and antiinflammatory intestinal mediators involved in portal hypertensive rats. Mediators Inflamm 2: 101-111, 2005

15. Chiu CJ, McArdle AH, Brown A and et al: Intestinal mucosal lesion in low-flow states. I. A morphological, hemodynamic, and metabolic reappraisal. Arch Surg 101: 478-483, 1970.

16. Jiang Y, Xu J, Zhou $\mathrm{C}$ and et al: Characterization of cytokine/ chemokine profiles of severe acute respiratory syndrome. Am J Respir Crit Care Med 171: 850-857, 2005.

17. Liu ZF, Tang YQ, Meng FS, Pan ZG, Peng N, Guo JQ and Su L: Study on the pathological changes in striated muscle, cardiac and smooth muscles in heat stroke in mice. Chin Crit Care Med 20: 755-757, 2008

18. Romanovsky AJ and Blatteis CM: Heat stroke: opioid-mediated mechanisms. J Appl Physiol 81: 2565-2570, 1996.

19. Leon LR, DuBose DA and Mason CD: Heat stress induces a biphasic thermoregulatory response in mice. Am J Physiol Regul Integr Comp Physiol 288: R197-R204, 2005.

20. Wilkinson DA, Burholt DR and Shrivastava PN: Hypothermia following whole-body heating of mice: effect of heating time and temperature. Int J Hyperthermia 4: 171-182, 1988.

21. Minnema MC, Chang AC, Jansen PM and et al: Recombinant human antithrombin III improves survival and attenuates inflammatory responses in baboons lethally challenged with Escherichia coli. Blood 95: 1117-1123, 2000.

22. Leon LR: Hypothermia in systemic inflammation: role of cytokines. Front Biosci 9: 1877-1888, 2004.
23. Lin MT, Kao TY, Su CF and Hsu SSF: Interleukin-1 $\alpha$ production during the onset of heat stroke in rabbits. Neurosci Lett 174: 17-20, 1994.

24. Meakins JL and Marshall JC: the gastrointestinal tract was called the 'motor' of multiple organ failure. Arch Surg 121: 197-201, 1986.

25. Hall DM, Buettner GR, Oberley LW, Xu L, Mattes RD and Gisolfi CV: Mechanisms of circulatory and intestinal barrier dysfunction during whole body hyperthermia. Am J Physiol Heart Circ Physiol 280: H509-H521, 2001.

26. Lambert GP, Gisolfi CV, Berg DJ, Moseley PL, Oberley LW and Kregel KC: Selected contribution: Hyperthermia-induced intestinal permeability and the role of oxidative and nitrosative stress. J Appl Physiol 92: 1750-1761, 2002.

27. Bouchama A, Al-Sedairy S, Siddiqui S, Shail E and Rezeig M: Elevated pyrogenic cytokines in heat stroke. Chest 104: 1498-1502, 1993.

28. Chang DM: The role of cytokines in heat stroke. Immunol Invest 22: 553-561, 1993.

29. Hershko DD, Robb BW, Luo GJ, Paxton JH and Hasselgren PO: Interleukin- 6 induces thermotolerance in cultured Caco- 2 cells independent of the heat shock response. Cytokine 21: 1-9, 2003.

30. Robb BW, Hershko DD, Paxton JH, Luo GJ and Hasselgren PO: Interleukin-10 activates the transcription factor C/EBP and the interleukin-6 gene promoter in human intestinal epithelial cells. Surgery 132: 226-331, 2002.

31. Hungness ES, Robb BW, Luo GJ, Hershko DD and Hasselgren PO: Hyperthermia-induced heat shock activates the transcription factor c/EBP-beta and augments IL-6 production in human intestinal epithelial cells. J Am Coll Surg 195: 619-626, 2002.

32. Oberholzer A, Oberholzer C and Moldawer LL: Interleukin-10: a complex role in the pathogenesis of sepsis syndromes and its potential as an anti-inflammatory drug. Crit Care Med 30: S58-S63, 2002.

33. Mattner F, Fischer S, Guckes S and et al: The interleukin-12 subunit p40 specifically inhibits effects of the interleukin-12 heterodimer. Eur J Immunol 23: 2202-2208, 1993. 